\title{
Čimbenici donošenja odluke birača - primjer izbora za gradonačelnika grada Zagreba 2017.
}

Predrag Haramija* pharamij@zsem.hr

Andrijana Mušura Gabor** amusura@zsem.hr
UDK: 324(497.521.2)

316.62:324

Prethodno priopćenje / Preliminary communication

Primljeno: 11. rujna 2017. Prihvaćeno: 11. siječnja 2018.

U radu se istražuje koliko su čimbenici koji su obično temelj donošenja odluke birača utjecali u slučaju izbora za gradonačelnika grada Zagreba 2017. Spoznaje se da prekratka i nevješto vođena izborna kampanja nije mogla promijeniti već prije formirane preferencije birača, a i uzrok je slabe prepoznatljivosti programa većine kandidata. Preferencije birača formiraju se na temelju osobina kandidata, a rezultat izbora ukazuje da je većini građana iskustvo upravljanja, odnosno dosadašnji rezultati kandidata, bilo znatno važnije od stranačke opredijeljenosti.

Ključne riječi: izbori, ponašanje birača, kandidati, izborni programi, izborna kampanja.

\section{Uvod}

Istraživanjima o ponašanju birača (vidi poglavlje 1.) zajedničko je to što smatraju da, u okružju slobodnih i demokratskih izbora, birači svoju odluku donose na temelju promišljanja, odnosno pod utjecajem jednog ili više sljedećih čimbenika: (1) stajališta prema nekom važnom javnom pitanju, odnosno svojstva programa kandidata i njihovih stranaka, (2) svojstva kandidata kao osobe, (3) ideološka orijentacija i identifikacija s nekom političkom strankom, (4) dosadašnji rezultati stranaka i kandidata pri obnašanju vlasti i (5) okolnosti, odnosno karakter same izborne kampanje. Ono u čemu se istraživanja razlikuju je ponajprije njihov odabir čimbenika kojega smatraju presudnijim, odnosno važnijim.

\footnotetext{
* Dr. sc. Predrag Haramija, Zagrebačka škola ekonomije i managementa, Jordanovac 110, Zagreb.

${ }^{* *}$ Dr. sc. Andrijana Mušura Gabor, Zagrebačka škola ekonomije i managementa, Jordanovac 110, Zagreb.
} 
Cilj ovog rada je istražiti koliko su i kako navedeni čimbenici utjecali u slučaju izbora za gradonačelnika grada Zagreba 2017., odnosno koji su čimbenici bili više, a koji manje važni pri donošenju odluke birača. Usporedivši spoznaje dosadašnjih istraživanja s okolnostima izbora za gradonačelnika grada Zagreba 2017. godine te okolnostima i rezultatima prethodnih izbora, postavili smo tri hipoteze:

H 1. Kratka izborna kampanja kandidata za gradonačelnika ne mijenja već formirane preferencije birača.

H 2. Ideološka orijentacija i identifikacija s nekom političkom strankom većini birača nije presudan čimbenik za donošenje odluke.

H 3. Dosadašnji rezultati i osobine kandidata za gradonačelnika važniji su čimbenik donošenja odluke birača od programskih odrednica kandidata o javnim pitanjima grada Zagreba.

Za provjeru navedenih hipoteza napravljena je usporedna analiza mogućih čimbenika donošenja odluke birača u izborima za gradonačelnika 2017. godine (pogl. 2). Da bismo detektirali građanima najvažnije probleme grada, poželjne osobine kandidata, stupanj upoznatosti s programima kandidata i prihvatljivost kandidata za gradonačelnika Grada Zagreba napravili smo i prigodnu predizbornu anketu (pogl. 3).

Za provjeru $\mathrm{H} 1$ služimo se usporedbom istraživanja rejtinga pojedinih kandidata prije početka službene izborne kampanje, napravljenih od strane agencija za istraživanje javnoga mnijenja, s rezultatima samih izbora (pogl. 2.2). Vodimo se pravilom da manja razlika između takvih anketa i rezultata izbora to znači manji utjecaj službene izborne kampanje.

Za provjeru točnosti $\mathrm{H} 2$ uspoređujemo osvojeni broj glasova kandidata u izborima za gradonačelnika s dobivenim glasovima stranaka u izborima za Gradsku skupštinu i stranaka na parlamentarnim izborima. Služimo se i predizbornim istraživanjima agencija za istraživanje javnog mnijenja o tome koje kandidate za gradonačelnika preferiraju birači pojedinih stranaka (pogl. 2.5).

$\mathrm{Za}$ provjeru točnosti $\mathrm{H} 3$ služimo se analizom podataka o okolnostima i svojstvima izborne kampanje (pogl. 2.1), odnosno usporedbom programskih odrednica i osobina kandidata s rezultatima izbora (pogl. 2.3 i 2.4). Kao ilustraciju mogućih tendencija predstavljamo i rezultate vlastite ankete (pogl. 3).

\section{Smjerovi i spoznaje istraživanja o ponašanju birača}

Vjerojatno najčešće pitanje političkih analitičara je kako predvidjeti ponašanje birača, tj. njihovu odluku za koga će glasovati. Istraživanja ponašanja birača počela su prije gotovo stotinu godina u SAD-u. Najstarije, a i prvo u kojem 
je primijenjena metoda ankete, jest ono koje su napravili Merriam i Goswell još 1923. da bi utvrdili razloge neizlaska na izbore. ${ }^{1}$ Postojanje razlike između političko-stranačkih opredjeljenja i stajališta prema društvenim i političkim pitanjima pojedinih skupina građana - bila je tema istraživanja koje je proveo Robinson 1932. godine. ${ }^{2}$

Kao godina početka prave znanstvene analize ponašanja birača često se navodi 1944. godina ${ }^{3}$ kad su Lazarsfeld i dr. objavili istraživanje čimbenika koji su utjecali na odluku birača na predsjedničkim izborima 1940. godine u SAD-u. ${ }^{4}$ U istraživanju su se služili metodom tzv. panel analize, a glavne varijable koje navode su političko opredjeljenje, stajališta prema kandidatima, socijalni status, odnosno društveni utjecaji.

Moglo bi se reći da su poteškoće u primjeni spoznaja tih ranih istraživanja na današnju situaciju: tvrdo pristajanje uz stajalište da socijalne karakteristike određuju političku preferenciju ili što precjenjuju ulogu stranačke lojalnosti te smatraju da većina birača zato ne mijenja opredjeljenje tijekom kampanje, odnosno da teme kampanje ne utječu na biračko opredjeljenje. ${ }^{5}$ Nedostatak ranijih istraživanja je i nedovoljno prepoznavanje utjecaja, odnosno ulogu medija u (dez)informiranju i manipulaciji birača.

Istraživanja nastala u drugoj polovici XX. stoljeću, a posebice ona nastala $u$ XXI. stoljeću, u obzir uzimaju znatno više čimbenika. Neki od tih čimbenika su, ovisno o okolnostima izbora, važniji, a neki ne. Potrebno je napraviti složen izračun koji u obzir uzima sve okolnosti. U izračun treba unijeti niz čimbenika: spol, rasu, kulturu, vjeru, političku situaciju u nekoj zemlji (pa i svijetu), teme koje dominiraju u javnosti, politička opredjeljenja, emocije, utjecaj medija, utjecaj društva te utjecaj prijatelja i članova obitelji. ${ }^{6}$ Kao vrlo važno pitanje smatraju i to jesu li birači odluku donijeli slobodno ili pod prisilom ili manipulacijom.

Novija se istraživanja mogu podijeliti u više skupina, ovisno o tome na koji se čimbenik donošenja odluke birača ponajviše usmjeruje.

${ }^{1}$ Usp. C. E. MERRIAM, H. F. GOSNELL, Non-Voting, Chicago, Chicago University Press, 1924.

${ }^{2}$ Usp. E. S. ROBINSON, Trends of the Voter's Mind, Journal of Social Psychology, 4 (1933) 265284

${ }^{3}$ Vidi: R. E. GOODIN, H. D. KLINGEMAN, A New Handbook of Political Science, Oxford, Oxford University Press, 1996, 39.

${ }^{4}$ P. LAZARSFELD, B. I. BERELSON, H. GAUDET, How the Voter Makes up His Mind in a Presidential Campaign, New York, Columbia University Press, 1944.

${ }^{5} \mathrm{U}$ nas je pristupe ranijih (kako ih naziva »klasičnih «) američkih istraživanja ponašanja birača analizirao Ivan Šiber. Dijeli ih u tri grupe, ovisno radi li se o »političko-sociološkom«, »političko-psihološkom « ili o »političko-ekonomskom « pristupu. Prva su usmjerena na socijalni položaj kao odrednicu političkog opredjeljenja, druga na stranačku identifikaciju birača, odnosno strukturu stavova o kandidatima i glavnim problemima (temama), a treća na važnost racionalnosti i vlastitog interesa u ponašanju birača. Vidi: I. ŠIBER, Tri klasična pristupa istraživanju ponašanja birača, Politička misao, 40 (2003) 2, 88-103.

${ }^{6}$ Usp. Paul A. BECK i dr., The social calculus of voting. Interpersonal, media, and organizational influences on presidential choices, American Political Science Review, 96 (2002) 1, 57-73. 


\subsection{Istraživanja usmjerena na utjecaj ideološke orijentacije $i$ identifikacije birača s nekom političkom strankom}

Istraživanja ove skupine slijede spoznaje radova koje su napravili Campbell i dr. ${ }^{7}$ Oni polaze od pretpostavke da je prosudba birača redovno pod utjecajem i ideološke orijentacije birača (desno, lijevo, konzervativno, liberalno itd.), odnosno pripadnosti ili identifikacije birača s nekom političkom strankom. Smatraju da su ti čimbenici »dugovječniji«, tj. formiraju stav koji se ne mijenja lako od izbora do izbora. Naime svojstva kandidata ili bilanca ostvarenog na vlasti su čimbenici kratka trajanja, mijenjaju se od izbora do izbora. Stranačka ili ideološka opredijeljenost je nešto trajnije i ne mijenja se od izbora do izbora. Glavna pitanja ili problemi u društvu su pak nešto između. Ona se mogu mijenjati od izbora do izbora no temeljna stajališta birača ovise o njihovoj ideološkoj opredijeljenosti. Tako je, po njima, odnos prema abortusu, troškovima obrane, socijalnoj skrbi i sl. unaprijed definiran ideološkom orijentacijom birača.

\subsection{Istraživanja usmjerena na utjecaj stajališta prema nekom važnom javnom pitanju, odnosno svojstva programa stranaka $i$ kandidata}

Ova istraživanja polaze od pretpostavke da su društvene vrijednosti i javna pitanja za koje se kandidati u svojim istupima i izjavama zalažu (tj. programske odrednice) ključne za određivanje individualnih preferencija birača na izborima. Birači će izabrati kandidate na temelju stajališta prema nekom važnom javnom pitanju, odnosno svojstvima programa kandidata, a kad se to ne dogodi onda uzroke traže u tome što kandidati nisu jasno izložili svoje programe ili što ih mediji nisu adekvatno prezentirali. ${ }^{8} \mathrm{Kad}$ kandidati jasno artikuliraju razlike svojih stajališta tad i birači imaju jasniju percepciju tih razlika i čvršće stavove za koga glasovati, a važno pitanje izbora je i stupanj u kome birači mogu sagledati razlike među kandidatima glede njihovih programa. ${ }^{9}$ Da bi stav kandidata o nekom javnom pitanju utjecao na odluku o glasovanju nužno je da i sami birači imaju stav o tom pitanju jer često se događa da sami birači nisu imali jasno određene stavove ili nisu uspjeli sagledati bitne razlike između stajališta kandidata.$^{10}$ Poimanje, odnosno razlikovanje, dobrog i lošeg često navodi bira-

7 Usp. A. CAMPBEll, G. GURIN, W. E. MILLER, The Voter Decides, Evanston, Row, Peterson\&Co, 1954; A. CAMPBELL, C. H. COOPER, Group Differences in Attitudes and Votes, Ann Arbor, Institute for Social Research, 1954.

${ }^{8}$ Usp. Norman H. NIE, Sidney VERBA, John R. PETROCIK, The Changing American Voter, Cambridge MA, Harvard University Press, 1976, 164-173.

9 Usp. Michael R. ALVEREZ, Information and Elections, Ann Arbor, University of Michigan Press, 1998, 109-156; Samuel, MERRILL, Bernard GROFMAN, A Unified Theory of Voting, Cambridge, Cambridge University Press, 1999, 1-9.

${ }^{10}$ Usp. Angus CAMPBELL i dr., The American Voter, New York, John Wiley, 1960, 168-187. 
če na to da bivaju skloniji upotrijebiti svoj glas da bi izbjegli ostvarenje političke platforme koju smatraju lošom nego da bi podržali onu koju smatraju dobrom. ${ }^{11}$

\subsection{Istraživanja usmjerena na utjecaj osobina (sposobnosti, kvaliteta, vrijednosti) kandidata}

Ova istraživanja polaze od pretpostavke da na glasovanje birača uvelike utječe percepcija osobnih kvaliteta i sposobnosti kandidata. Biračima su najvažnije osobine kandidata: iskustvo, poštenje, moralnost, suosjećajnost i liderske sposobnosti. ${ }^{12}$ Dimenzija integriteta posebno je važna i oličena je u poštenju i pouzdanosti kandidata. Dimenzija kompetentnosti podrazumijeva iskustvo i znanje kandidata; tvrde da birači nerado glasaju za osobu kojoj nedostaje iskustva i sposobnosti za neku vodeću dužnost. Postoji i dimenzija suosjećajnosti; birači favoriziraju kandidate koji se doimaju spremnima pomoći drugima. Te četiri dimenzije ili svojstva kandidata mogu varirati u važnosti, ovisno o karakteru ili okružju izbora. Od javnosti percipirane osobine kandidata često se nazivaju »imidž«. Imidž kandidata je presudan na predsjedničkim izborima. ${ }^{13}$ Istraživanje o tomu u kojim okolnostima je biračima imidž kandidata važniji od njegovih programskih odrednica upućuje na to da je imidž najpresudniji u slučaju sličnosti programskih stajališta. ${ }^{14}$ Imidž kandidata u politici treba graditi po principima korporativnog brendiranja, ${ }^{15} \mathrm{u}$ čemu se slaže više istraživanja, ${ }^{16}$ a načinjen je i priručnik za brendiranje kandidata. ${ }^{17}$ Svi ti autori smatraju da je brendiranje kandidata dugotrajan proces i da ga treba započeti više mjeseci (pa i godina) prije početka same izborne kampanje.

${ }^{11}$ Usp. Daniel KAHNEMAN, Amos TVERSKY, Choices, values, and frames, Cambridge, Cambridge University Press, 2000, 67-71; Daniel KAHNEMAN, Amos TVERSKY, Loss aversion in riskless choice. A reference-dependent model, The Quarterly Journal of Economics, Oxford Journals, 106 (1991) 4, 1039-1061.

${ }^{12}$ Usp. Warren E. MILLER, J. Merrill SHANKS, The New American Voter, Cambridge MA, Harvard University Press, 1996, 425-427, 416.

${ }^{13}$ Usp. Kenneth L. HACKER, Presidential Candidate Images, New York, Rowman \& Littlefield, 2004, 178-179.

${ }^{14}$ Usp. Timothy M. O'KEEFE, Kenneth G. SHEINKOPF, The voter decides: Candidate image or campaign issue?, Journal of Broadcasting, 18 (1974) 4.

${ }^{15}$ Usp. F. GUZMAN, V. SIERRA, A political candidate's brand image scale. Are political candidates brands?, Journal of Brand Management, 17 (2009) 3, 207-217.

${ }^{16}$ Usp. Marcus PHIPPS, Jan BRACE-GOVAN, Colin JEVRONS, The duality of political brand equity, European Journal of Marketing, 44 (2010) 3-4, 496-514; Kenneth M. COSGROVE, Personal political branding at state level, u: Jennifer Lees-Marshment, Brian Conley and Kenneth Cosgrove (ur.), Political Marketing in the US, New York, Routledge, 2014; Wojciech CWALINA, Andrzej FALKOWSKI, Political Branding. Political Candidates Positioning Based on Inter-Object Associative Affinity Indeks, Journal of Political Marketing, 14 (2015) 1-2, 152174.

${ }^{17}$ Usp. Lisa SPILLER, Jeff BERGNER, Branding the Candidate. Marketing Strategies to Win Your Vote, Praeger Publishers, 2011. 


\subsection{Istraživanja usmjerena na razlike u ponašanju birača ovisno o vrsti izbora}

Ova istraživanja polaze od pretpostavke da građani koriste različite kriterije donošenja odluka ovisno o tomu je li riječ o lokalnim izborima, parlamentarnim izborima ili referendumu. Na lokalnim izborima ljudi ponajprije nastoje glasovati za one koji mogu ostvariti njihove (najčešće praktične materijalne) potrebe u području svakodnevnog života koje im je važno, na izborima državne razine ljudi obično glasuju na temelju svog političkog uvjerenja, a referendum od birača traži da glasuju za ili protiv nekog jasno određenog javnog pitanja. ${ }^{18}$ Po njima su lokalni izbori najpogodniji okvir za donošenje pragmatične racionalne odluke jer je najčešće pitanje koje si birači na njima postavljaju žive li danas bolje nego prije četiri (ili pet) godina, koliko već traje mandat neke vlasti. Iako dosadašnji rezultati kandidata pri obnašanju vlasti, odnosno rezultati stranaka kojima pripadaju utječu na birače na svim vrstama izbora, taj utjecaj je najsnažniji na lokalnim izborima, posebice ako je kandidat već obnašao dužnost za koju se natječe.

\subsection{Istraživanja usmjerena na utjecaj emocija te manipulativnih tehnika izborne kampanje na birače}

Ova istraživanja uočavaju da je važno pitanje današnjih izbora koliko je odluka koju smo donijeli pod utjecajem manipulativnih tehnika izborne kampanje (negativna kampanja, manipulativni PR, zavaravajuće oglašavanje itd.), odnosno utjecaja (često pristranih) medija. Dva su moguća utjecaja izborne kampanje, odnosno medija na vrijednosnu prosudbu, tj. odluku birača. ${ }^{19}$ Prvi je u sadržaju informacija koji birači dobivaju putem medija; jesu li one istinite ili nisu i, posljedično, je li naša odluka plod dezinformacija. Drugi je u karakteru samih informacija, jesu li one oblikovane tako da potiču emocije koje mogu utjecati na vrijednosnu prosudbu, odnosno odluku birača. Korištenje apela na emocije u političkim kampanjama je općepoznata praksa i uobičajeno sredstvo da bi se povećala podrška svom kandidatu ili umanjila onom suparničkom. Brader uočava da se u članova stranke često nastoji potaknuti pozitivne emocije poput entuzijazma i vjere u svog kandidata, da bi se potaknuo izlazak na

\footnotetext{
${ }^{18}$ Usp. Ioannis ANDREADIS, Theodore CHADJIPADELIS, Differences in voting behavior, Proceedings of the $20^{\text {th }}$ IPSA World Congress. Fukuoka, 2006, 1-13; http://paperroom.ipsa.org/ papers/paper_5402.pdf (11.09.2017).

${ }^{19}$ Usp. Piotr WINKIELMAN i dr., Affective influence on judgments and decisions. Moving towards core mechanisms, Review of General Psychology, 11 (2007) 2, 179-192.
} 
izbore i politički aktivizam, dok se istodobno nastoji potaknuti emocije straha i strepnje glede protukandidata. ${ }^{20}$

Na ponašanje birača najviše utječu emocije poput ljutnje (gnjeva, mržnje), straha, tjeskobe i ponosa. ${ }^{21}$ Kažu da neke emocije otežavaju racionalnu prosudbu, a neke potiču. Tako ljutnja, gnjev i mržnja pojačavaju utjecaj stereotipa i predrasuda pri donošenju odluka i na njih se vrlo često oslanja u izbornim kampanjama. Štoviše, temelj su negativnih kampanja. Osobe s osjećajem ljutnje ili gnjeva manje se oslanjaju na prosudbu argumenata ili činjenica, odnosno osobe pod utjecajem tih osjećaja manje su sklone tražiti informacije o kandidatu na izborima i provode manje vremena proučavajući stajališta kandidata na internetu. ${ }^{22}$ Strah ima suprotan učinak, tj. ljudi pod osjećajem straha detalinije procesuiraju informacije pri donošenju odluka, odnosno provode više vremena tražeći informacije na internetu. ${ }^{23}$ I anksioznost (tjeskoba, strepnja) u okružju izbora pojačava političku pozornost i slabi oslanjanje na identifikaciju s strankom pri donošenju odluka o izboru te tako poboljšava sposobnost donošenja odluka. Međutim drugo tvrde suprotno, odnosno da manje preferirani kandidati stvaraju osjećaj anksioznosti. ${ }^{24}$

Neki smatraju da je apel na (nacionalni) ponos važan čimbenik pri donošenju odluka na američkim predsjedničkim izborima, no ipak slijedi iza onog učinka identifikacije sa strankom. ${ }^{25}$ Kazuju i da su se apeli na ponos pokazali učinkovitiji i pri motiviranju birača na izlazak na izbore, iako im učinak nije tako jak kao kod apela na sram. Što je složenije (sofisticiranije) političko okružje, to su birači skloniji emotivno reagirati na političke događaje te tako skloniji i zabludi pri odluci na izborima. ${ }^{26}$

Hrvatska istraživanja ponašanja birača mogla su stvarno započeti tek nakon uvođenja višestranačja 1990. godine, tj. kad su birači dobili mogućnost izbora između više opcija. U njima je zastupljen spektar usmjerenja sličan onima u stranim istraživanjima. Istraživanje o ponašanju birača na izborima 1992. godine pokazalo je da je socijalni status bio važan čimbenik stranačkoga opredje-

\footnotetext{
${ }^{20}$ Usp. Ted BRADER, Campaigning for hearts and minds. How emotional appeals in political ads work, Chicago, University of Chicago Press, 2006, 2-4.

${ }^{21}$ Usp. Michael T. PARKER, Linda M. ISBELL, How I vote depends on how I feel the differential impact of anger and fear on political information processing, Psychological Science, 21 (2010) $4,548-550$.

${ }^{22}$ Usp. Nicholas A. VALENTINO i dr., Is a worried citizen a good citizen? Emotions, political information seeking, and learning via the Internet, Political Psychology, 29 (2008) 2, 247-273.

${ }^{23}$ Usp. George E. MARCUS, Russell W. NEUMAN, Michael MACKUEN, Affective intelligence and political judgment, Chicago, University of Chicago Press, 2000, 142.

${ }^{24}$ Usp. Jonathan McDonald LADD, Gabriel S. LENZ, Does anxiety improve voters' decision making?, Political Psychology, 32 (2011) 2, 347-361.

${ }^{25}$ Usp. Christopher FINN, Jack GIASER, Voter affect and the 2008 US Presidential election. Hope and race mattered, Analyses of Social Issues and Public Policy, 10 (2010) 1, 262-275.

${ }^{26}$ Usp. Patrick R. MILLER, The emotional citizen: emotion as a function of political sophistication, Political Psychology Wiley, 32 (2011) 4, 575-600.
} 
ljenja. ${ }^{27}$ Istraživana su stajališta građana o kandidatima i strankama, a potom i mogući uzroci promjene biračke odluke. ${ }^{28}$ Istraživani su i uzroci apstinencije na izborima. ${ }^{29}$ Učinak izborne kampanje tema je više radova. Istraživan je utjecaj personalizirane kampanje, ${ }^{30}$ pozitivan ili negativan utjecaj suvremenih kampanja, ${ }^{31}$ utjecaj sustava vrijednosti, odnosno moralnih emocija, ${ }^{32}$ utjecaj tzv. negativne kampanje, ${ }^{33}$ utjecaj stranačke identifikacije. ${ }^{34}$ Istraživani su razlozi pobjede Milana Bandića na izborima u gradu Zagrebu 2013. godine za gradonačelnika, ${ }^{35}$ sa zaključkom da Bandić podjednako uspijeva prikupiti glasove birača HDZ-a i SDP-a jer »koristi samo one identitetske motive koji ne sukobljavaju ljevicu i desnicu«. ${ }^{36}$

\section{Usporedna analiza mogućih čimbenika donošenja odluke građana u izborima za gradonačelnika grada Zagreba 2017.}

\subsection{Okolnosti izbora i svojstva izborne kampanje}

Treće nedjelje svibnja svake četvrte godine održavaju se u Republici $\mathrm{Hr}$ vatskoj izbori za lokalnu predstavničku vlast i izbori za lokalnu izvršnu vlast. Tako su se i izbori za gradonačelnika grada Zagreba 2017. održali u nedjelju 21. svibnja (prvi krug izbora). Budući da gradonačelnik grada Zagreba nije izabran

${ }^{27}$ Usp. Stanko RIHTAR, Izbori u Hrvatskoj 1992: Razlozi opredjeljivanja birača, Društvena istraživanja, 1 (1992) 2, 275-284, 275; Ivan RIMAC, Socijalni status i politička odluka - izbori 1992., Društvena istraživanja, 1 (1992) 2, 265-274, 265.

${ }^{28}$ Usp. Goran MILAS, Mišljenje javnosti o hrvatskim političarima i političkim strankama kao pokazatelj dimenzionalnosti i prirode hrvatskog političkog prostora, Društvena istraživanja, 1 (1992) 2, 245-264; Goran MILAS, Mišljenje građana o poželjnim karakteristikama predsjednika Republike, u odnosu na vlastito biračko opredjeljenje, Društvena istraživanja, 1 (1992) 2, 285295; Goran MILAS, Razlozi nedosljednosti. Tko i zašto mijenja glasačku odluku?, Društvena istraživanja, 9 (2000) 4-5, 475-493.

${ }^{29}$ Usp. Vesna LAMZA POSAVEC, Apstinencija na izborima za Hrvatski sabor 2003. godine. Tko i zašto nije glasovao?, Društvena istraživanja, 13 (2004) 3, 383-404, 385.

${ }^{30}$ Usp. Mirjana KASAPOVIĆ, Personalizacija izbora. Mit ili stvarnost?, Društvena istraživanja, 13 (2004) 3, 363-381, 366.

${ }^{31}$ Usp. Marijana GRBEŠA, Suvremene izborne kampanje i kako one utječu na demokratski proces, Politička misao, 42 (2005) 1, 49-59, 56.

${ }^{32}$ Usp. Ivan FERIĆ, Sustav vrijednosti kao odrednica dominantnih političkih preferencija, Društvena istraživanja, 17 (2008) 4-5, 615-629; Stanko RIHTAR, Ivan FERIĆ, Moralne emocije i polarizacija birača, Društvena istraživanja, 17 (2008) 4-5, 631-645.

${ }^{33}$ Usp. Predrag HARAMIJA, Jagoda POROPAT DARRER, Negativna izborna kampanja - uzroci, posljedice i etička dimenzija. Primjer izbora za tijela lokalne samouprave u Republici Hrvatskoj 2013., Obnovljeni život, 69 (2014) 1, 19-36.

${ }^{34}$ Usp. Andrija HENJAK, Stranačka identifikacija i granice stranačke mobilizacije u Hrvatskoj nakon 2000. godine, Političke perspektive, 1 (2011) 1, 29-55.

${ }^{35}$ Usp. Andrija HENJAK, Bandićev trijumf na prvim pravim lokalnim izborima, Političke analize, 4 (2013) 15, 33-36.

${ }^{36}$ Isto, 35. 
u prvom krugu (uvjet je više o 50 \% glasova), to je 4. lipnja 2017. održan drugi krug izbora u kojem sudjeluju dva kandidata s najviše glasova u prvom krugu izbora.

Grad Zagreb je glavni grad Republike Hrvatske i u njemu je četvrtina hrvatske populacije te gotovo polovica gospodarskih resursa. Vlast u Zagrebu donosi i snažan utjecaj na gospodarske, komunalne, kulturne, obrazovne i druge strukture. Zato su od svih izbora na lokalnoj razini u Republici Hrvatskoj, izbori za gradonačelnika i skupštinu grada Zagreba najvećim političkim strankama najvažniji. Naime, da bi gradonačelnik Zagreba mogao provoditi svoje odluke potrebna mu je i većina u Gradskoj skupštini, čiji se članovi (njih 50) biraju proporcionalnom izbornom metodom.

Najjače stranke u državi, SDP i HDZ, u ove su izbore ušle opterećene nesređenim odnosima i nepovjerenjem u svojoj zagrebačkoj organizaciji. To je vjerojatno razlog zašto u svojim redovima ne pronalaze kandidata koji bi mogao ugroziti aktualnog dugogodišnjeg (već 16 godina) gradonačelnika Milana Bandića. HDZ u izbore ulazi s kandidatom za gradonačelnika (Drago Prgomet) koji je relativno kasno određen i uz otpor u svojoj gradskoj organizaciji te ima protukandidata (Bruna Esih) koja je na listi iste stranke izabrana za zastupnicu u Saboru. SDP pak ne izlazi sa svojim kandidatom već podupire kandidata HNS-a (Anka Mrak Taritaš).

Važno je istaknuti i posebnost ovih izbora - kratkoću kampanje. Od svih dosadašnjih izbora, službena kampanja za ove je trajala najkraće, tek desetak dana - od 7. do 19. svibnja 2017. To je svakako prekratko da bi javnosti nepoznati kandidati uspjeli (kroz termine osigurane u medijima) predstaviti sebe i svoje programe. U tom smislu kratkoća kampanje je dala veliku prednost javnosti otprije dobro poznatim kandidatima.

I ono malo vremena koje imaju kandidati ne koriste na učinkovit način da bi predstavili javnosti sebe i svoje programe. Većina je kandidata smatrala da kampanju mogu osmisliti i voditi sami, odnosno uz pomoć stranačkih suradnika te da nema potrebe za angažiranjem stručnjaka, tj. agencija za odnose s javnošću. ${ }^{37}$ Svi tiskaju plakate i letke te koriste internetske stranice, a oni s više sredstava izrađuju i televizijske i radijske spotove, no u njima nema snažnijih i pamtljivih poruka. Ni slogani (koji bi trebali biti koncentrat poruka kampanje) nisu dojmljivi; Milan Bandić ima slogan »Živim Zagreb«, Anka Mrak Taritaš u izborima za gradonačelnika koristi slogane »Mrak-gradonačelnica« $\mathrm{i} » \mathrm{Za}-$ jednoDoPromjene«, Sandra Švaljek ima slogan »Nezavisna«, Drago Prgomet »Briga za ljude, briga za Zagreb«, Marko Sladoljev »Vaš sused, gradonačelnik«,

\footnotetext{
${ }^{37}$ Usp. Maja ŠURINA, Kampanja u Zagrebu bez PR agencija? Gotovo svi tvrde da su »sam svoj majstor«, tportal.hr, 14. svibnja 2017.

https://www.tportal.hr/vijesti/clanak/kampanja-u-zagrebu-bez-pr-agencija-gotovo-svi-tvrdeda-su-sam-svoj-majstor-20170512 (17.05.2017).
} 
Bruna Esih »S Brunom za Zagreb«, Ivan Lovrinović »Zagreb mora prodisati« i Tomislav Tomašević »Javni interes, borbenost, znanje«.

U lokalnim izborima vrlo važan osobni kontakt $\mathrm{s}$ biračima uglavnom se svodi na stranačke skupove, tribine i štandove te posjete tržnicama. Za nastupa u terminima osiguranim u medijima (javna sučeljavanja), umjesto da izlažu prednosti svojih programa, većina kandidata usmjerila se ponajprije na kritiku aktualnog gradonačelnika, a počesto i jedni drugih. Pri tome nisu svjesni da negativna kampanja na lokalnim izborima u Hrvatskoj uglavnom ne donosi koristi. ${ }^{38}$ Važno je spomenuti da su dva kandidata u nizu medija tijekom kampanje prozivani za koruptivne aktivnosti. ${ }^{39}$ Vjerojatno je da građani koji su glasali za njih te optužbe nisu uzeli za istinu već su ih smatrali dijelom negativne kampanje jer je riječ o dvama kandidatima koji su dobili najviše glasova i ušli u drugi krug izbora.

Sve u svemu, iz okolnosti i karaktera kampanje se može zaključiti da ona ne uspijeva potaknuti snažnije emocije prema kandidatima ni upoznati birače s programima kandidata.

\subsection{Usporedba rezultata izbora ${ }^{40} \mathrm{~s}$ anketama radenim prije početka izborne kampanje - pokazatelj utjecaja kampanje}

Rezultati prvog kruga izbora pokazali su da aktualni gradonačelnik vodi s 30,87 \% glasova, a prati ga s 24,48 \% Anka Mrak Taritaš (HNS-ova kandidatkinja koju je podržao i SDP). Sandra Švaljek (Nezavisna lista-HSLS) je treća s 19,14\%. Slijedi nezavisna Bruna Esih koja je s 10,98 \% iznenađenje izbora. HDZov kandidat Drago Prgometa dobiva tek 5,6 \%. Tomislav Tomašević (Zagreb je naš) osvaja 3,94 \%, Ivan Lovrinović (Živi zid) dobiva $2 \%$, a Marko Sladoljev (Most) 1,88 \%. U drugi krug izbora ulaze Bandić i Mrak Taritaš, te na kraju Bandić pobjeđuje s 51,79 \%, nasuprot 46,07 \% Mrak Taritaš. Konačan rezultat izbora kazuje da se građani nisu odlučili za promjenu gradonačelnika, većina

\footnotetext{
${ }^{38}$ U 9 od 10 slučajeva kandidati koji su se okrenuli negativnoj kampanji na lokalnim su izborima u RH 2013. doživjeli poraz [usp. Predrag HARAMIJA, Jagoda POROPAT DARRER, Negativna izborna kampanja - uzroci, posljedice i etička dimenzija. Primjer izbora za tijela lokalne samouprave u Republici Hrvatskoj 2013., Obnovljeni život, 69 (2014) 1, 19-37].

${ }^{39}$ Anka Mrak Taritaš je tijekom izborne kampanje doživjela u medijima »aferu Gunja«, odnosno optužbe da je kao ministrica graditeljstva višestruko preplatila radove na obnovi kuća u poplavljenim područjima, Milan Bandić je već niz godina u medijima opterećen optužbama za nezakonite postupke. Godine 2014. uhićen je zbog sumnje na nezakonita postupanja u Zagrebačkom holdingu i Gradu Zagrebu. Nakon puštanja iz pritvora, vraća se na dužnost gradonačelnika.

${ }^{40}$ Rezultati izbora prema: Državno izborno povjerenstvo Republike Hrvatske, Informacija o izborima članova predstavničkih tijela jedinica lokalne i područne (regionalne) samouprave i općinskih načelnika, gradonačelnika i župana te njihovih zamjenika - 2017., (20.06.2017) XXI. GRAD ZAGREB, www.izbori.hr/izbori/ws.nsf/54F87B28512ED1B6C12581460039375B/\$FI LE/Z21_GRAD_ZAGREB.pdf (11.09.2017).
} 
je izabrala zadržavanje postojećeg stanja i glasala za kandidata kojeg najbolje poznaju.

U odnosu na izbore za gradonačelnika 2013. razvidan je stanovit pad popularnosti Milana Bandića, naime on je na izborima 2013. u prvom krugu osvojio 47 \%, a u drugom 65 \% glasova. Vjerojatno je Anka Mrak Taritaš 2017. svojom kampanjom bolje uspjela okupiti glasove nezadovoljnih Milanom Bandićem nego kandidat SDP-a 2013. godine (Rajko Ostojić). Moguće je i da je na ovim izborima dio HDZ-ovih pristaša, umjesto Milanu Bandiću, glas dao Bruni Esih.

U odnosu na broj zastupnika u skupštini, rezultati izbora su slični onima na prošlim lokalnim izborima 2013. godine. Bandićeva lista (23,03 \%) i lista SDPove koalicije $(20,78 \%)$ osvajaju sličan broj mandata. HDZ ponavlja loš rezultat (11,96 \%). Iznenađenje izbora 2017. je svakako lista Brune Esih s osvojenih 8,23 $\%$ te lista novoosnovane platforme Zagreb je naš sa 7,64 \%. Mostova je lista osvojila tek 4,93 \%, a stranka Živi zid 4,53 \%.

Predizborna istraživanja dobro su predvidjela rezultate izbora. Sva su najavljivala da Milan Bandić ima velike izglede biti ponovno izabran na čelnu funkciju grada Zagreba. Po svim anketama on uvjerljivo vodi, a na drugom mjestu je Anka Mrak Taritaš (SDP-HNS) te vrlo joj blizu Sandra Švaljek (nezavisni kandidat uz podršku HSLS-a). U tom smislu iznenađenja nije bilo, osim što su neke osobe koje su najavljivale kandidaturu (i u njima ostvarile relativno dobar rezultat) zamijenjene drugima (mjesto Ivana Pernara kandidat Živog zida je bio Ivan Lovrinović). ${ }^{41}$

Razlika između rezultata istraživanja preferencija birača napravljenih prije početka kampanje i samih rezultata izbora ukazuje na moguć utjecaj kampanje na promjenu preferencija birača. Znači, u slučaju ovih izbora, takva utjecaja nije bilo, preferencije birača utvrđene su prije početka (službene) kampanje i nisu se mijenjale.

\subsection{Utjecaj osobina kandidata za gradonačelnika grada Zagreba 2017.}

U izborima za gradonačelnika grada Zagreba 2017. sudjelovalo je osam kandidata. ${ }^{42}$ Navodimo ih poredane po rezultatu ostvarenom na prvom krugu izbora: Milan Bandićc ${ }^{3}$ je kandidat stranke Bandić Milan 365 - Stranka rada i

\footnotetext{
${ }^{41}$ Usp. Damira GREGORET, Utrka za gradonačelnika - prvo ekskluzivno predizborno istraživanje za Zagreb. Ima li Bandić i šesti mandat u rukama i zašto HDZ strahuje od Brune Esih?, (26.03.2017), www.vijesti.rtl.hr/novosti/hrvatska/2653975/prvo-predizbornoistrazivanje-utrke-za-gradonacelnika-zagre ba/ (11.09.2017); v. i Detaljna statistika - izborne preferencije u gradu Zagrebu (28.03.2017), www.vijesti.rtl.hr/lokalni-izbori-2017-statistickicentar/2654895/lokalni-izbori-2017-zagreb/?ticker_type = latest_news (11.09.2017).

${ }^{42} \mathrm{U}$ vlastitoj anketi razmatramo šest kandidata koji su svoju kandidaturu najavili do travnja 2017., tj. prije početka anketiranja.

${ }^{43}$ Milan Bandić je rođen 1955. godine u općini Grude (BiH). Godine 1974. upisuje Fakultet političkih znanosti Sveučilišta u Zagrebu, gdje i diplomira. Od 1983. radi u Općinskom
} 
solidarnosti, Anka Mrak Taritašs4 je kandidatkinja Hrvatske narodne stranke (HNS) i Socijaldemokratske partije (SDP). Sandra Švaljek ${ }^{45}$ je nezavisan kandidat podržan od Hrvatske socijalnoliberalne stranke (HSLS). Bruna Esih ${ }^{46}$ je nezavisan kandidat (poslije izbora formira stranku Nezavisni za Hrvatsku). Drago Prgomet ${ }^{47}$ je kandidat Hrvatske demokratske zajednice (HDZ). Tomislav Tomašević ${ }^{48}$ je kandidat političke platforme Zagreb je naš uz podršku Nove ljevice, ORaH-a, Radničke fronte i Za grad. Stranka Živi zid je (umjesto Ivana Pernara koji je najavljivao kandidaturu) u zadnji tren kandidirala Ivana Lovrinovića. ${ }^{49}$ Marko Sladoljev ${ }^{50}$ je kandidat stranke Most.

komitetu Saveza komunista na Peščenici u Zagrebu. Tajnik Gradskog odbora SDP-a postaje 1993., a 1997. godine i predsjednik. Gradonačelnikom Zagreba prvi put postaje 2000. godine kao kandidat SDP. Godine 2009. prestaje biti članom SDP-a, da bi 2013. kao neovisni kandidat po peti put izabran za gradonačelnika. Stranku Bandić Milan 365 - Stranka rada i solidarnosti osnovao je 2015. godine i kao njezin kandidat se 2017. natječe za šesti mandat gradonačelnika. Oženjen, jedno dijete.

${ }^{44}$ Anka Mrak Taritaš je rođena 1959. godine u Bjelovaru. Diplomira 1983. na Arhitektonskom fakultetu Sveučilišta u Zagrebu. Od 1983. radi u Ministarstvu graditeljstva, a 2003. prelazi u Gradski zavod za planiranje razvoja grada Zagreba, gdje je pročelnica. Od 2005. godine radi u Upravi za prostorno uređenje u Ministarstvu graditeljstva i prostornog uređenja. Od 2011. je zamjenica ministra, a od 2012. do početka 2016. godine je ministrica. Predsjednica zagrebačkog ogranka HNS-a. Udana, dvoje djece.

${ }^{45}$ Sandra Švaljek je rođena u Krapini 1970. godine. U Zagrebu 1988. godine upisuje Ekonomski fakultet gdje diplomira, magistrira te doktorira. Od 1992. godine radi na Ekonomskom institutu, a na Ekonomskom fakultetu Sveučilišta u Zagrebu vodi kolegije iz područja financija i poreza. Kao kandidat na Bandićevoj listi 2013. postaje zamjenica gradonačelnika, a 2014. godine je obnašala dužnost gradonačelnice. Po razrješenju s te dužnosti ostaje nezavisna zastupnica u Gradskoj skupštini. Udana, dvoje djece.

${ }^{46}$ Bruna Esih je rođena u Splitu 1975. godine. Diplomira filozofiju i kroatologiju na Hrvatskim studijima Sveučilišta u Zagrebu, magistrira 2006. te upisuje doktorski studij povijesti na Hrvatskim studijima. Od 2001. znanstveni novak na Institutu Ivo Pilar. Od 2004. predsjednica je udruge Hrvatski križni put koja istražuje poslijeratne partizanske i komunističke zločine. $\mathrm{Na}$ listi HDZ je 2016. izabrana u Sabor. Udana je.

${ }^{47}$ Drago Prgomet je rođen 1965. godine u općini Derventa (BiH). Diplomira 1990. godine na Medicinskom fakultetu u Banjoj Luci, a 1996. diplomirao je i na Medicinskom fakultetu Sveučilišta u Zagrebu, gdje i magistrira te doktorira. Od 1990. do 1998. radi u Općoj bolnici Slavonski Brod, a od 2000. godine u KBC-u Rebro u Zagrebu. Od 2010. je profesor na Medicinskom fakultetu Sveučilišta u Zagrebu i pročelnik Katedre za otorinolaringologiju. Od 2003. do 2006. zastupnik HDZ-a u Hrvatskom saboru. Godine 2012. je izabran za zamjenika predsjednika HDZ-a. Stranci Most pristupa 2015. godine, ali tad biva i izbačen iz nje. Potom osniva stranku HRID, a 2016. godine se vraća u HDZ. Oženjen, dvoje djece.

${ }^{48}$ Tomislav Tomašević je rođen u Zagrebu 1982. godine. Diplomirao je politologiju na Fakultetu političkih znanosti Sveučilišta u Zagrebu, a 2013. na Sveučilištu u Cambridgeu magistrirao je u području zaštite okoliša. Radi kao voditelj Instituta za političku ekologiju. Oženjen.

${ }^{49}$ Ivan Lovrinović, rođen je 1960. godine u Gučoj Gori (BiH). Diplomirao, magistrirao te 1995. godine doktorirao na Ekonomskom fakultetu Sveučilišta u Zagrebu. Od 2006. redoviti je profesor na Katedri za financije Ekonomskoga fakulteta Sveučilišta u Zagrebu. Na listi Mosta 2015. godine biva izabran u Hrvatski sabor, no potom formira vlastitu stranku naziva Promijenimo Hrvatsku.

${ }^{50}$ Marko Sladoljev je rođen 1973. u Zagrebu. PTT-obrazovni centar završava 1992. i 1996. godine Katolički bogoslovni fakultet u Zagrebu. Od 1996. do 2016. profesor je vjeronauka u OS Ante Kovačića u Zagrebu. Od 2016. zastupnik je Mosta u Hrvatskom saboru. Oženjen. 
Svojstva (osobine, kvalitete) kandidata moguće je pokušati iščitati iz njihovih javno dostupnih životopisa. ${ }^{51}$ Među kandidatima ima nešto sličnosti. Većina kandidata (6 od njih 8) nisu rođeni u Zagrebu, ali svi su završili visoku naobrazbu u Zagrebu. Svi kandidati (osim jednog) su u braku i imaju jedno ili više djece.

Kandidati se razlikuju po dobi, najstariji kandidat ima 62, a najmlađi 35 godina. Uvelike se razlikuju po struci, odnosno fakultetima koje su završili, poslovima koje su radili te po iskustvu u javnim upravnim poslovima. Dva kandidata su po izobrazbi politolozi, dva su ekonomisti, po jedan je liječnik, arhitekt, povjesničar i vjeroučitelj. Od osam kandidata tek tri imaju iskustvo u javnim upravnim poslovima, jedan je dugogodišnji gradonačelnik (M. Bandić), jedna kandidatkinja je vodila gradski ured te potom bila ministrica (A. Mrak Taritaš), a jedna je bila zamjenica gradonačelnika te i obnašala dužnost gradonačelnice (Sandra Švaljek). Mogli bismo zaključiti da je upravo to iskustvo građanima bilo najvažnije jer su tri kandidata s najvećim brojem glasova upravo ovi navedeni. Važnost upravljačkog iskustva naglašavaju i istraživanja koja tvrde da na lokalnim izborima ljudi ponajprije nastoje glasovati za one koji mogu ostvariti njihove (najčešće praktične materijalne) potrebe u području svakodnevnog života koje im je važno, ${ }^{52}$ a za to je pak važna dimenzija kompetentnosti kandidata. ${ }^{53}$

\subsection{Utjecaj programskih odrednica kandidata}

Programske odrednice svih kandidata se u nizu rješenja koje nude često preklapaju. Gotovo svi kandidati nude niz građevinskih projekata, odnosno slična rješenja prometnih gužvi, komunalne infrastrukture, problema otpada, nedostatka dječjih vrtića itd. Nekoliko kandidata spominje i problem korupcije, a dvoje bi smanjilo i prirez. U tom smislu programi kandidata se preklapaju uz tek poneku iznimku. ${ }^{54}$ Primjer takve iznimke je Bruna Esih koja jedina traži promjenu imena Trga maršala Tita. Navodimo one programske odrednice koje su kandidati nastojali najviše isticati u kampanji, odnosno one u kojima se (eventualno) razlikuju od drugih: Anka Mrak Taritaš obećava niz građevinskih projekata: napraviti mrežu biciklističkih staza, dovršiti pojedine spojeve ulica,

\footnotetext{
${ }^{51}$ Podaci o kandidatima koje navodimo napravljeni su prema životopisima dostupnima na portalu Biografija.com, https://www.biografija.com/ (11.09.2017).

${ }^{52}$ Usp. Ioannis ANDREADIS, Theodore CHADJIPADELIS, Differences in voting behavior, Proceedings of the $20^{\text {th }}$ IPSA World Congress. Fukuoka, 2006, 1-13; http://paperroom.ipsa.org/ papers/paper_5402.pdf (11.09.2017).

${ }_{53}$ Warren E. MILLER, J. Merrill SHANKS, The New American Voter, Cambridge MA, Harvard University Press, 1996, 425-427, 416.

${ }^{54}$ Usp. Jelena RASTOČIĆ, Bitka za Zagreb, (18.05.2017), https://dnevnik.hr/vijesti/hrvatska/lokalni-izbori-2017-bitka-za-zagreb-tko-ce-i-s-kakvim-programom-vladati-gradom---477066. html (11.09.2017).
} 
izgradnju dva mosta: prvi u produžetku Strojarske, drugi kraj Jaruna i uklanjanje azbesta s vrtića i škola. Drago Prgomet nudi izgradnju nove dječje bolnice u Novom Zagrebu, formiranje novoga središta Novog Zagreba, rješavanje prometnog čepa u Sesvetama, novi most kraj Jaruna i više dječjih vrtića.

Tomislav Tomašević kao prioritete za grad Zagreb ističe jeftine i kvalitetne komunalne usluge, svima dostupne javne usluge (vrtići, škole, bolnice, starački domovi), povećanje zaposlenosti mladih kroz »zelenu industrijalizaciju«. Sandra Švaljek, koja (kao i drugi) predlaže nove mostove i prometna rješenja te nove škole i dječje vrtiće, ali se i usmjerava na nove izvore prihoda grada, racionalnije upravljanje gradskom imovinom kao i smanjenje prireza. Ivan Lovrinović u kampanji ukazuje na problem napuštenih poslovnih prostora, blokiranih ljudi, nezaposlenih, ovršenih te iseljavanja iz Zagreba. Najavljuje velike smjene u gradskoj upravi.

Marko Sladoljev nudi rješavanje problema otpada, racionalno upravljanje novcima građana, gradnju jarunskog mosta, a prometne gužve bi smanjio denivelacijom križanja. Razlikuje se od drugih kandidata po tome što traži ukidanje naknada političarima u školskim odborima i upravnim vijećima vrtića te, što je isticao, jedini je među kandidatima rođeni Zagrepčanin. Bruna Esih je u javnosti ponajviše ostala upamćena kao jedini kandidat koji izričito traži promjenu imena Trga maršala Tita, no usmjerila se i na rješavanje problema korupcije, odnosno načina upravljanja gradom. Milan Bandić se od svih kandidata razlikuje po tome što u kampanji uopće ne navodi programske odrednice (to je prepustio svojim zamjenicama) već u javnim nastupima ponajviše ističe dosadašnje zasluge, $t j$. do sada učinjeno. ${ }^{55}$

U okolnostima vrlo kratke izborne kampanje kandidati teško da su mogli jasno prezentirati javnosti (male) razlike svojih programa. Birači zato svoje preferencije ne mogu temeljiti na razlikama programa već se usmjeruju na osobine, odnosno »imidž« kandidata. Navedeni zaključak u skladu je sa spoznajama istraživanja ${ }^{56}$ koja kazuju da su biračima osobine (odnosno imidž) kandidata važniji od njegovih programskih odrednica, posebice u slučaju sličnosti programskih stajališta. Budući da, u situaciji kratke kampanje, javnosti manje poznati kandidati ne uspijevaju predstaviti svoje kvalitete, to su imali prednost kandidati otprije dobro poznati u javnosti. To su oni koji su već duže prisutniji u medijima zbog javnih dužnosti koje obnašaju.

\footnotetext{
${ }^{55}$ Navodi da »radi 365 dana u godini« te je značajno povećao zaposlenost, izgradio brojne škole, vrtiće i parkove za djecu, izgradio obilaznicu na zapadu Zagreba, uredio Bundek, izgradio fontane, izdvajao značajnija sredstva za kulturu grada Zagreba itd.

${ }^{56}$ Usp. Timothy M. O'KEEFE, Kenneth G. SHEINKOPF, The voter decides. Candidate image or campaign issue?, Journal of Broadcasting, 18 (1974) 4, 402-412.
} 


\subsection{Utjecaj ideološke i stranačke opredijeljenosti}

Iako se kandidati na izborima obično razlikuju po političkoj, odnosno ideološkoj orijentaciji, ovim izborima je svojstveno da većina kandidata nisu osobe čvrste stranačke i ideološke opredijeljenosti. Naime, čak su četiri kandidata dosad mijenjali stranačku pripadnost, a dvoje je kandidata nezavisno, tj. ne pripadaju niti jednoj stranci. U takvom okružju teško je očekivati da će se većina birača u donošenju svoje odluke voditi ideološkim i stranačkim preferencijama.

Na problem »stranačke lojalnosti« ukazala su i predizborna istraživanja. Ukazuju da Dragu Prgometa podržava tek 25 \% HDZ-ovih birača, Brunu Esih njih 17 $\%$, a čak trećina njih već u prvom krugu bira Milana Bandića. Ankete su ukazivale da bi u drugom krugu više od 70 \% HDZ-ovih birača odabralo Bandića ako se suoči s Ankom Mrak Taritaš, a ako se suoči s Sandrom Švaljek čak njih 74 \%. ${ }^{57}$

Rezultati prvog kruga izbora jasno su pokazali da je ideološka orijentacija i identifikacija s nekom političkom strankom na ovim izborima bila čimbenik slabijeg utjecaja. To je posebice razvidno u slučaju HDZ-a. Polovica birača te stranke je dala glas kandidatima drugih stranaka - kandidat HDZ je dobio dvostruko manje glasova od svoje stranke (5,6 \% naspram $11,9 \%$, pretpostavlja se da su glasovi otišli Milanu Bandiću i Bruni Esih), a sama stranka skoro trostruko manje glasova nego što dobiva na parlamentarnim izborima (u izbornim jedinicama 1, 2, 6 i 7 koje obuhvaćaju dijelove grada Zagreba rezultat HDZ-a na parlamentarnim izborima 2016. godine je od 32 do $35 \%$ ). Treba pripomenuti da je dvostruko veća potpora listi HDZ nego kandidatu te stranke, slučaj koji se dogodio i na izborima 2013. godine. ${ }^{58}$ Istodobno, teško da se može reći da pobjednik izbora pripada $\mathrm{u}$ »desni centar« kamo se ideološki svrstava HDZ. ${ }^{59}$ Treba spomenuti da su i kandidati nekih drugih stranaka dobili dvostruko manje glasova od lista svojih stranaka; kandidat MOST-a Marko Sladoljev dobiva $1,8 \%$, a lista $4,9 \%$, kandidat stranke »Živi zid« Ivan Lovrinović $2 \%$, a lista 4,5 $\%$, kandidat platforme »Zagreb je naš« dobiva 3,9\%, a lista 7,6 \%. SDP pak nije imao svoga kandidata već podupire Anku Mrak Taritaš, kandidatkinju HNS-a koja uspijeva biti druga po broju glasova jer je kao i Sandra Švaljek (treća po broju glasova) uspjela prikupiti znatan dio glasova onih nezadovoljnih aktualnim gradonačelnikom. Važno je pripomenuti i da su Sandra Švaljek i Bruna Esih, treći i četvrti kandidat po broju osvojenih glasova, bile nezavisni kandidati, tj. osobe bez stranačke pripadnosti.

\footnotetext{
${ }^{57}$ Usp. Damira GREGORET, Utrka za gradonačelnika - prvo ekskluzivno predizborno istraživanje za Zagreb. Ima li Bandić i šesti mandat u rukama i zašto HDZ strahuje od Brune Esih?, (26.03.2017), www.vijesti.rtl.hr/novosti/hrvatska/2653975/prvo-predizbornoistrazivanje-utrke-za-gradonacelnika-zagre ba/ (11.09.2017); v. i Detaljna statistika - izborne preferencije u Gradu Zagrebu (28.03.2017), www.vijesti.rtl.hr/lokalni-izbori-2017-statistickicentar/2654895/lokalni-izbori-2017-zagreb/?ticker_type =latest_news (11.09.2017).

${ }^{58} \mathrm{Na}$ izborima za gradonačelnika 2013. kandidatkinja HDZ-a bila je Margareta Mađerić.

${ }^{59}$ Milan Bandić aktivno u politiku ulazi 1983. godine kao član SKH, a do 2009. godine je član SDP-a.
} 


\section{Istraživanje stajališta o prioritetima grada Zagreba, poželjnim osobinama $i$ upoznatosti s programima kandidata te prihvatljivosti kandidata za gradonačelnika}

\subsection{Sudionici i postupak}

Anketa je provedena u travnju 2017. (prije početka službene izborne kampanje) na prigodnom uzorku od 183 građana Zagreba koji imaju pravo glasa na gradskim izborima. Za potrebe prikupljanja sudionika, regrutirani su studenti visoke poslovne škole. Studenti su u kvartovima u kojima žive provodili anketu na prigodnom uzorku sudionika. Kriterij odabira sudionika bio je mogućnost glasanja na gradskim izborima (punoljetni građani grada Zagreba) te da po mjestu stanovanja ispitanika budu ravnomjerno zastupljene sve gradske četvrti Zagreba (njih 17). To smo smatrali važnim jer rezultati dosadašnjih izbora pokazuju da postoje značajne razlike u stranačkim preferencijama građana ovisno o četvrti u kojoj žive. ${ }^{60}$

Budući da je uzorak prigodan, ne odražava opće karakteristike građana Zagreba. Prema spolu, uzorak sačinjava $46 \%$ muškaraca i $53 \%$ žena, prosječne starosti 32 godine ( $X=32,11 ; S D=14,24 ; \mathrm{Min}=20$; Maks=79). Prema mjestu rođenja, 69 \% ispitanih je iz Zagreba, dok je 24 \% rođeno izvan Zagreba. Prosječan broj godina života u Zagrebu je 33 ( $X=32,83, S D=13,56$, Min=1, Maks=79). S obzirom na stupanj obrazovanja, $26 \%$ sudionika ima srednju stručnu spremu, $24 \%$ sudionika se izjasnilo studentima, 40 \% ih ima visoku stručnu ili školsku spremu te $7 \%$ imaju magisterij ili doktorat.

Anketa je bila sastavljena od pet grupa pitanja: 1. prioriteti Grada Zagreba (10 pitanja) koje građani smatraju ključnima za poboljšanje života, odnosno funkcioniranje grada Zagreba, ${ }^{61} 2$. poželjne osobine gradonačelnika grada Zagreba (10 pitanja), tj. vrijednosti (sposobnosti, kvaliteta) koje ispitanici smatraju najvažnijima pri odlučivanju za jednog od kandidata, ${ }^{62} 3$. prihvatljivost kandidata (6 kandidata) ${ }^{63}$ - od ispitanika se traži da ocijene koliko svaki od

\footnotetext{
${ }^{60} \mathrm{U}$ gradu Zagrebu ima 17 četvrti. Milan Bandić najviše glasova na izborima redovno osvaja u rubnim četvrtima, a najmanje u centru i rezidencijalnim sjevernim dijelovima grada.

${ }^{61}$ Prioriteti grada Zagreba odabrani su prema ključnim problemima uočenim u javnim raspravama, izbornim kampanjama i napisima u medijima u zadnjih 20 godina.

${ }^{62}$ Poželjne osobine kandidata definirali smo prema onima u knjizi: Warren E. MILLER, J. Merrill SHANKS, The New American Voter, Cambridge MA, Harvard University Press, 1996. te s spoznajama istraživanja vrednota: Josip BALOBAN ur., U potrazi za identitetom, komparativna studija vrednota. Hrvatska $i$ Europa, Zagreb, Golden marketing, 2005; Josip BALOBAN, Krunoslav NIKODEM, Siniša ZRINŠĆAK, Vrednote u Hrvatskoj i u Europi, Zagreb, Kršćanska sadašnjost, 2014.

${ }^{63}$ Kandidate koje navodimo u anketi odabrali smo na temelju njihovih izjava o kandidaturi koje su dali u javnim medijima do 30. ožujka 2017. tako da nisu zastupljeni kandidati koji su se prijavili kasnije.
} 
navedenih kandidata za gradonačelnika grada Zagreba može riješiti najvažnije probleme grada Zagreba i svojim osobinama ispuniti očekivanja, 4. stupanj upoznatosti s programom kandidata (6 kandidata), te 5. demografska pitanja (6 pitanja). Ljestvica na kojoj su ispitanici procjenjivali stupanj prioritetnosti pojedinih pitanja, važnost pojedinih osobina, stupanj prihvatljivosti kandidata te upoznatost $s$ programima, imala je sedam stupnjeva (uopće se ne slažem -1 , potpuno se slažem -7 ). Anketa je bila anonimna, s kratkim vremenom rješavanja.

\subsection{Rezultati i rasprava}

Tablica 1. Prosječne vrijednosti ocjene prioritetnosti pojedinog pitanja u gradu Zagrebu.

\begin{tabular}{|l|c|}
\hline \multicolumn{1}{|c|}{ PITANJE } & Prosječna ocjena \\
\hline Razvoj gospodarstva i smanjenje nezaposlenosti & 5,8 \\
\hline Rješavanje problema korupcije & 5,7 \\
\hline Bolji sustav osnovne, srednje i visoke izobrazbe & 5,5 \\
\hline Bolji javni prijevoz i rješavanje prometnih gužvi & 5,4 \\
\hline Niža cijena i bolje kvaliteta komunalnih usluga & 5,3 \\
\hline Bolja skrb za siromašne, stare i nemoćne & 5,3 \\
\hline Bolja zdravstvena zaštita & 5,2 \\
\hline Smanjivanje stope prireza & 5,2 \\
\hline Veća sigurnost građana odnosno smanjenje stope kriminala & 5,1 \\
\hline Bolja zaštita okoliša i više zelenih površina & 5,0 \\
\hline
\end{tabular}

Tablica 1. prikazuje podatke za prvu grupu pitanja glede stupnja prioritetnosti pojedinih problema u gradu Zagrebu. Prosječne vrijednosti ukazuju da se na prvom mjestu nalazi pitanje razvoja gospodarstva i smanjenje nezaposlenosti $(X=5,8)$, nakon čega je $s$ nešto manjom prosječnom vrijednosti procijenjeno pitanje rješavanja problema korupcije $(5,7)$. Na trećem mjestu prioriteta našlo se pitanje boljeg sustava izobrazbe $(X=5,5)$. Kao zadnje, prema prosječnim vrijednostima, ispitanici su procijenili pitanje bolje zaštite okoliša i više zelenih površina $(X=5,0)$. Važno je naglasiti da su sva pitanja procijenjena visokim ocjenama, pri čemu su razlike u prosjecima vrlo male.

Rezultati pokazuju da građani jasno prepoznaju i smatraju vrlo važnim sva pitanja koja smo naveli kao nužna za poboljšanje života građana, odnosno bolje funkcioniranje grada Zagreba (prosječna ocjena iznad 5) i posebno ih je znakovito usporediti s onima o upoznatosti građana s programima kandidata (vidi tablicu 2.) koji pokazuju da je stupanj upoznatosti građana s programima kandidata relativno nizak (od 2,4 do 4,1). 
Tablica 2. Prosječne vrijednosti upoznatosti s programima pojedinih kandidata.

\begin{tabular}{|l|c|c|}
\hline & Prosječna ocjena & Standardna devijacija \\
\hline Milan Bandić & 4,1 & 2,0 \\
\hline Bruna Esih & 3,6 & 1,9 \\
\hline Anka Mrak Taritaš & 3,4 & 2,1 \\
\hline Marko Sladoljev & 3,0 & 1,8 \\
\hline Drago Prgomet & 2,5 & 1,9 \\
\hline Sandra Švaljek & 2,4 & 1,8 \\
\hline
\end{tabular}

Tablica 2 ukazuje na stupanj upoznatosti s programima kandidata. Na pitanje koliko su upoznati s programima pojedinih kandidata, ispitanici procjenjuju da su najviše upoznati s programom Milana Bandića $(x=4,1)$. Zatim, s programom Brune Esih $(x=3,6)$ te s programom Anke Mrak Taritaš $(x=3,4)$. Najmanji stupanj upoznatosti ispitanici iskazuju s programom Sandre Švaljek $(x=2,4)$.

Osim, također, visokih variranja rezultata oko prosječnih vrijednosti, možemo zaključiti da je, općenito, stupanj upoznatosti s programima kandidata relativno nizak. Niti jedna vrijednost se nalazi u visokom stupnju upoznatosti. Ovakav podatak je kontradiktoran pretpostavci racionalnog odlučivanja da bi preferencije prema kandidatima trebale biti utemeljene na poznavanju njihovih programa. Slaba upoznatost s programima kandidata znači da ili kandidati nisu imali jasno određene stavove ili birači nisu uspjeli sagledati bitne razlike između stajališta kandidata. ${ }^{64}$ Treba ipak pripomenuti da je anketa rađena prije početka službene izborne kampanja, no za pretpostaviti je da vrlo kratka i nevješto vođena izborna kampanja teško može promijeniti navedene rezultate.

Tablica 3. Prosječne procjene važnosti pojedinih osobina gradonačelnika grada Zagreba.

\begin{tabular}{|l|c|}
\hline \multicolumn{1}{|c|}{ PITANJE } & Prosječna ocjena \\
\hline Izraženih organizacijskih i liderskih sposobnosti & 5,9 \\
\hline Znanje barem jednog stranog jezika & 5,8 \\
\hline Dokazanog poštenja i istinoljubivosti & 5,7 \\
\hline Dokazano uspješna u dosadašnjem poslu & 5,7 \\
\hline Komunikativna, energična i vesela & 5,1 \\
\hline Susretljiva, suosjeća s potrebitima i spremna pomoći & 5,0 \\
\hline Visoke naobrazbe, doktor ili bar magistar znanosti & 4,9 \\
\hline Dobrog imovinskog stanja, tj. materijalno neovisna & 4,5 \\
\hline Obiteljska osoba & 4,4 \\
\hline Rođenjem iz Zagreba ili s više od 20 godina življenja u Zagrebu & 4,4 \\
\hline
\end{tabular}

${ }^{64}$ Jedini izuzetak bila je Bruna Esih koja je pokrenula pitanje preimenovanja Trga maršala Tita. I najveća pozitivna i statistički značajna korelacija između upoznatosti s programom kandidata i stupnjem njegove prihvatljivosti, nalazi se kod Brune Esih $(0,65)$. 
U tablici 3 daju se prosječne procjene vrijednosti pojedinih osobina poželjnih za gradonačelnika grada Zagreba. Vidljivo je da su sve prosječne vrijednosti na pozitivnom dijelu ljestvice, što znači da ispitanici procjenjuju da su sve osobine jako poželjne. Ipak, najpoželjnija je organizacijska i liderska sposobnost $(x=5,9)$, zatim, znanje barem jednog stranog jezika $(x=5,8)$ te, na trećem mjestu, dokazanog poštenja i istinoljubivosti i dokazane uspješnosti u dosadašnjem poslu $(x=5,7)$. Nešto manje važnim se procijenila značajka ima li kandidat obitelj te je li rođenjem iz Zagreba $(x=4,4) \cdot{ }^{65}$

Tablica 4. Prosječan stupanj prihvatljivosti pojedinih kandidata

\begin{tabular}{|l|c|c|}
\hline & Prosječna ocjena & Standardna devijacija \\
\hline Milan Bandić & 3,7 & 2,1 \\
\hline Anka Mrak Taritaš & 3,5 & 1,9 \\
\hline Sandra Švaljek & 3,5 & 1,9 \\
\hline Bruna Esih & 3,5 & 2,1 \\
\hline Drago Prgomet & 2,7 & 1,7 \\
\hline Marko Sladoljev & 2,6 & 1,7 \\
\hline
\end{tabular}

Tablica 4. prikazuje prihvatljivost pojedinih kandidata prema procjeni građana koliko svaki od navedenih kandidata za gradonačelnika može riješiti najvažnije probleme grada Zagreba i svojim osobinama ispuniti očekivanja. Ispitanicima je najprihvatljiviji kandidat Milan Bandić $(x=3,7)$. Nakon njega, na drugom mjestu prihvatljivosti su, Sandra Švaljek, Anka Mrak Taritaš te Bruna Esih $(x=3,5)$. Manje su prihvatljivi kandidati Drago Prgomet $(x=2,7)$ i Marko Sladoljev $(x=2,6)$. Iz prosječnih vrijednosti vidimo da se većina nalazi u nižem dijelu ljestvice, što bi značilo da su ispitanicima kandidati generalno malo do srednje prihvatljivi. Niti jedan se kandidat ne ističe prema visokom prosječnom stupnju prihvatljivosti (stupanj prihvatljivosti je u rasponu od 2,6 do 3,7). Usporedimo li ove podatke s onima o poželjnim osobinama kandidata (vidi tablicu 3.) koji kazuju da sve osobine koje smo naveli građani smatraju važnima (raspon od 4,4 do 5,9) jasno je da niti jednog od kandidata ovih izbora anketirani građani ne sagledavaju kao idealnog, odnosno kao osobu koja u najvećoj mjeri ima sve poželjne osobine. Ipak, u prva tri najprihvatliivija kandidata moguće je uočiti »organizacijske i liderske sposobnosti«, tj. osobinu koju anketirani građani najviše vrednuju $(5,9)$. I rezultati prvog kruga izbora u skladu su s rezultatima ove ankete; u prva tri kandidata nema velikih odskakanja u broju glasova $(30,87 \%, 24,48 \%, 19,14 \%)$, a i poredak svih kandidata po broju osvojenih glasova sličan je poretku u ovoj tablici. Mogli bismo reći da su građani svoj glas odlučili dati onima koje percipiraju »najmanje

\footnotetext{
${ }^{65} \mathrm{U}$ tom smislu je i jedini od kandidata koji je rođen u Zagrebu (Marko Sladoljev) pogriješio kad je to isticao u svojoj kampanji kao prednost nad drugim kandidatima te ostvario vrlo slab rezultat. Kandidati koji su isticali svoje organizacijske sposobnosti su dobili znatno više glasova.
} 
lošim«. Ipak, ako pogledamo standardne devijacije, gdje redom imamo visoke vrijednosti, možemo zaključiti kako oko svakog kandidata postoji visok raspon od neprihvatljivosti do prihvatljivosti. To znači da su postojale jasne razlike $u$ tome koga skupine birača smatraju »najviše lošim«.

Treba spomenuti da su u takvim okolnostima građani skloni usmjeriti veću pozornost i na osobe koje su uz kandidata. To je prepoznao Milan Bandić koji je (kao i na prošlim izborima) uz svoje ime vezao i kvalitetnu izbornu listu (sastavljenu od niza uglednih osoba).

Iako smo zaključili da većina građana odluku o tome za koga će glasovati teško da je mogla donijeti na temelju programa, ipak možemo pokušati ustanoviti postoji li među kandidatima »iznimka koja potvrđuje pravilo«, tj. osoba čiji je program bio važniji čimbenik odluke onih koji su glasovali za tog kandidata. Radi toga napravili smo međukorelacije upoznatosti s programima kandidata i njihovom prihvatljivosti. ${ }^{66}$

Tablica 5. Međukorelacije upoznatosti s programima kandidata i njihovom prihvatljivošću.

\begin{tabular}{|c|c|c|c|c|c|c|c|}
\hline & & \multicolumn{6}{|c|}{ Prihvatljivost kandidata } \\
\hline & & $\begin{array}{l}\text { Milan } \\
\text { Bandić }\end{array}$ & $\begin{array}{l}\text { Bruna } \\
\text { Esih }\end{array}$ & $\begin{array}{c}\text { Anka } \\
\text { Mrak } \\
\text { Taritaš }\end{array}$ & $\begin{array}{c}\text { Drago } \\
\text { Prgomet }\end{array}$ & $\begin{array}{c}\text { Marko } \\
\text { Sladoljev }\end{array}$ & $\begin{array}{l}\text { Sandra } \\
\text { Švaljek }\end{array}$ \\
\hline \multirow{6}{*}{ 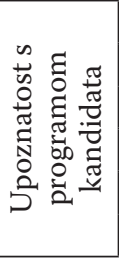 } & M. Bandić & $0,39^{* * *}$ & & & & & \\
\hline & B. Esih & & $0,65^{\text {**** }}$ & & & & \\
\hline & A. Mrak Taritaš & & & $0,43^{* * *}$ & & & \\
\hline & D. Prgomet & & & & $0,47 * *$ & & \\
\hline & M. Sladoljev & & & & & $0,56^{* \% *}$ & \\
\hline & S. Švaljek & & & & & & $0,46^{* * *}$ \\
\hline
\end{tabular}

** Značajno na razini $p<0,01$; "Značajno na $p<0,05$.

Tablica 5 ukazuje na to da najveća pozitivna i statistički značajna korelacija postoji u slučaju Brune Esih $(0,65)$, nezavisne kandidatkinje koja je s osvojenih $11 \%$ glasova bila iznenađenje izbora. To znači da su oni koji su glasali za nju to učinili ponajprije zbog njena programa. Točnije zbog zahtjeva u njezinu programu (koji ne nalazimo u programima drugih kandidata) za promjenom imena Trga maršala Tita. Mogli bismo reći da se (za razliku od drugih kandidata) racionalnost glasanja za B. Esih manje temelji na njenim osobinama (one su javnosti slabije poznate), a više na identifikaciji s najzapaženijom odrednicom njena programa.

\footnotetext{
${ }^{66} \mathrm{~S}$ obzirom na to da su dosadašnji rezultati ukazali da je prosječan stupanj upoznatosti $\mathrm{s}$ programima kandidata u nižem dijelu ljestvice, ne mogu se očekivati statistički značajne korelacije s prioritetima grada Zagreba. Slično je i glede korelacije stupnja prihvatljivosti kandidata s poželjnim osobinama gradonačelnika. Zato prikaz tih korelacija ne prikazujemo i ne interpretiramo.
} 


\section{Zaključak}

U slučaju izbora za gradonačelnika grada Zagreba 2017. pokazalo se da su neki od čimbenika donošenja odluke birača utjecali znatnije od drugih kod određivanja individualnih preferencija birača u gradu Zagrebu.

Vrlo kratka (službena) kampanja nije dala dovoljno vremena kandidatima za izlaganje svojih programa. Međutim, $u$ obzir treba uzeti i to da su se programi većine kandidata u nizu odrednica preklapali, a (u većini slučajeva) i sama kampanja je nevješto vođena te su birači teško mogli sagledati važne razlike između stajališta kandidata (osim iznimke kod B. Esih). Kampanja ne uspijeva promijeniti već formirane preferencije birača, no to je tako samo zbog njene kratkoće. Kratka (ali i uglavnom nevješto vođena) izborna kampanja prednost daje kandidatima otprije dobro poznatim javnosti. U tom smislu mogli bi zaključiti da se naša prva hipoteza (H 1) pokazala djelomično potvrđenom.

Kroz rezultate prvog kruga izbora razvidno je da treći i četvrti kandidat po broju osvojenih glasova uopće nisu bile stranačke osobe, a kandidati za gradonačelnika čak četiriju stranaka; HDZ, Most, Živi zid i Zagreb je naš dobivaju dvostruko manje glasova od lista svojih stranaka, tj. polovica birača tih stranaka nije im dala svoj glas. To govori da je ideološka orijentacija i identifikacija s nekom političkom strankom na ovim izborima (kao i na onima 2013. god.) bila čimbenik slabijeg utjecaja, odnosno u prilog točnosti naše druge hipoteze (H 2.)

Zbog okolnosti i karaktera kampanje, programske odrednice kandidata (a koje su obično važan čimbenik racionalnog donošenja odluke birača) nisu u većoj mjeri na ovim izborima mogle utjecati na odluku birača. Istodobno, dosadašnji rezultati kandidata pri obnašanju vlasti su imali utjecaja na birače - pobjednik izbora natjecao se za čak šesti mandat i percepcija njegovih rezultata opredjeljivala je birače za i protiv. Da je percepcija osobnih kvaliteta i sposobnosti kandidata, posebice iskustva u upravljanju, odnosno organizacijskih i liderskih sposobnosti u većoj mjeri utjecala na preferencije birača jasno govore rezultati izbora. Naime, tri kandidata koji su osvojili najviše glasova u prvom krugu izbora su osobe poznate javnosti po iskustvu vođenja tijela gradske ili državne uprave. $U$ tom smislu pokazalo se da je naša treća hipoteza $(H$ 3) uvelike točna.

U broju osvojenih glasova prvih triju kandidata nema većih odskakanja, što ukazuje na to da se niti jedan od njih ne percipira kao znatno prihvatljiviji većini građana od drugih. Pobjedi Milana Bandića na izborima svakako doprinosi i to što je uz svoje ime vezao kvalitetnu izbornu listu (sastavljenu od niza uglednih osoba) te što njegovi protukandidati nisu uzeli u obzir činjenicu da im negativna kampanja, u hrvatskim okvirima, ne donosi korist već samo štetu. 
Predrag Haramija* - Andrijana Mušura Gabor***

Factors for making a voter's decision - an example of the election for the Mayor of Zagreb 2017.

\section{Summary}

The paper explores the extent to which factors considered to be the basis for the decision-making of the voters have influenced the election of the mayor of Zagreb 2017. Too short and poorly managed election campaign was not able to change before it formed voter's preference, and is responsible for weak recognition of the program of most candidates. Voters 'preferences are formed on the basis of the candidate's characteristics. Result of the election suggests that for the majority of the citizens' management experience of the candidates was far more important than party engagement.

Keywords: elections, voter behavior, candidates, election programs.

(na engl. prev. Tanja Markeljević)

\footnotetext{
* Predrag Haramija, PhD, Zagreb School of Economics and Management; Address: Jordanovac 110, HR-10000 Zagreb, Croatia; E-mail: pharamij@zsem.hr.

**Andrijana Mušura Gabor, PhD, Zagreb School of Economics and Management; Address: Jordanovac 110, HR-10000 Zagreb, Croatia; E-mail: amusura@zsem.hr.
} 